\title{
Clinical Outcomes After Lung Stereotactic Body Radiation Therapy in Patients With or Without a Prior Lung Resection
}

Citation for published version (APA):

Hou, Y., Hermann, G., Lewis, J. H., Aerts, H. J., Baldini, E. H., Chen, A. B., Colson, Y. L., Hacker, F. L., Killoran, J. H., Kozono, D. E., Wagar, M., Wee, J. O., \& Mak, R. H. (2018). Clinical Outcomes After Lung Stereotactic Body Radiation Therapy in Patients With or Without a Prior Lung Resection. American Journal of Clinical Oncology-Cancer Clinical Trials, 41(7), 695-701.

https://doi.org/10.1097/COC.0000000000000344

Document status and date:

Published: 01/07/2018

DOI:

10.1097/COC.0000000000000344

Document Version:

Publisher's PDF, also known as Version of record

Document license:

Taverne

Please check the document version of this publication:

- A submitted manuscript is the version of the article upon submission and before peer-review. There can be important differences between the submitted version and the official published version of record.

People interested in the research are advised to contact the author for the final version of the publication, or visit the DOI to the publisher's website.

- The final author version and the galley proof are versions of the publication after peer review.

- The final published version features the final layout of the paper including the volume, issue and page numbers.

Link to publication

\footnotetext{
General rights rights.

- You may freely distribute the URL identifying the publication in the public portal. please follow below link for the End User Agreement:

www.umlib.nl/taverne-license

Take down policy

If you believe that this document breaches copyright please contact us at:

repository@maastrichtuniversity.nl

providing details and we will investigate your claim.
}

Copyright and moral rights for the publications made accessible in the public portal are retained by the authors and/or other copyright owners and it is a condition of accessing publications that users recognise and abide by the legal requirements associated with these

- Users may download and print one copy of any publication from the public portal for the purpose of private study or research.

- You may not further distribute the material or use it for any profit-making activity or commercial gain

If the publication is distributed under the terms of Article $25 \mathrm{fa}$ of the Dutch Copyright Act, indicated by the "Taverne" license above, 


\title{
Clinical Outcomes After Lung Stereotactic Body Radiation Therapy in Patients With or Without a Prior Lung Resection
}

\author{
Ying Hou, MD,* Gretchen Hermann, MA,* John H. Lewis, PhD, * \\ Hugo J. Aerts, PhD, ${ }^{*} \dagger \$$ Elizabeth H. Baldini, MD, ${ }^{*} \dagger$ Aileen B. Chen, MD, ${ }^{*}+$ \\ Yolonda L. Colson, MD, PhD, $\dagger \|$ Fred L. Hacker, PhD,*† \\ Joseph H. Killoran, PhD, * $\dagger$ David E. Kozono, MD, PhD, * + Matthew Wagar, MS,* \\ Jon O. Wee, MD, $\dagger \|$ and Raymond H. Mak, MD* $\dagger$
}

Objectives: Tumor control (TC), toxicity and survival, following stereotactic body radiation therapy (SBRT) were compared between patients with and without a prior lung resection (PLR).

Materials and Methods: The study is comprised of 130 patients with 141 peripheral tumors treated with SBRT at our institution from 2009 to 2013. Primary TC and lobar control (LC) were defined per RTOG 0236. Toxicity was scored using Common Terminology Criteria for Adverse Events version 4.0. Survival/TC and toxicity were compared between patients with and without PLR using the Kaplan-Meier method and cumulative incidence, respectively. Fine and Gray regression was used for univariable/multivariable analysis for radiation pneumonitis (RP).

Results: Of the 130 patients with median age 70 years (range, 42 to 93 y), 50 had undergone PLR (median time between PLR and SBRT: $33 \mathrm{mo}$; range, 1 to 206 ), including pneumonectomy (12\%), lobectomy $(46 \%)$, wedge resection $(42 \%)$. With a median follow-up of 21 months in survivors, the PLR group had better TC (1-y 100\% vs. 93\%; $P<0.01)$ and increased grade $\geq 2$ (RP; 1 -y $12 \%$ vs. $1 \% ; P<0.01)$. OS was not significantly different between the 2 groups ( $1-\mathrm{y} 91 \%$ vs. $85 \%$; $P=0.24)$. On univariable/multivariable analyses, biologically effective dose was associated with TC (hazard ratios, $0.97 ; 95 \%$ confidence interval, $0.94-0.999 ; P=0.04)$. Chemotherapy use was associated with grade $\geq 2 \mathrm{RP}$ for all patients (hazard ratios, 14.92; 95\% confidence interval, 5.68-39.21; $P<0.0001)$ in multivariable analysis. PLR was not associated with increased RP in multivariable analysis.

Conclusions: Patients with PLR who receive lung SBRT for lung tumors have high local control and relatively low toxicity. SBRT is an excellent option to treat second lung tumors or pulmonary metastases in patients with PLR.

Key Words: stereotactic body radiation therapy, lung cancer, prior lung resection, clinical outcomes, radiation pneumonitis

(Am J Clin Oncol 2018;41:695-701)

From the Departments of *Radiation Oncology; $\$$ Radiology, Dana-Farber Cancer Institute/Brigham and Women's Hospital; †Harvard Medical School; \|Division of Thoracic Surgery, Brigham and Women's Hospital, Boston, MA; and §Department of Radiation Oncology (MAASTRO), GROW Research Institute, Maastricht University, Maastricht, The Netherlands.

This work was funded in part by a Kaye Award.

Presented as a poster at ASTRO 2014.

R.H.M. has stock ownership of Celgene Inc. The other authors declare no conflicts of interest.

Reprints: Raymond H. Mak, MD, Dana-Farber Cancer Institute/Brigham and Women's Hospital, Harvard Medical School, 450 Brookline Ave., JF518, Boston, MA 02115-5450. E-mail: rmak@partners.org.

Copyright (C) 2016 Wolters Kluwer Health, Inc. All rights reserved.

ISSN: $0277-3732 / 18 / 4107-0695$

DOI: $10.1097 /$ COC.0000000000000344
In the United States, lung cancer is the leading cause of cancer-related deaths ${ }^{1}$ with a 5 -year survival rate for early stage (IA-IIB) non-small cell lung cancer (NSCLC) of only $36 \%$ to $73 \%{ }^{2}$ Surgery remains the standard treatment for patients with clinical stage I and II NSCLC. Nevertheless, for patients with inoperable lung cancers because of multiple comorbidities or those who refuse surgery, stereotactic body radiation therapy (SBRT) has emerged as an excellent treatment option. Previous prospective $e^{3-5}$ and retrospective ${ }^{6-8}$ studies of different SBRT regimens have demonstrated high local control ( $80 \%$ to $90 \%)$, high overall survival (OS) ( $50 \%$ to $60 \%)$ and high cancer-specific survival $(60 \%$ to $70 \%)$ at 2 to 3 years. SBRT is well tolerated, and the observed incidence of symptomatic radiation pneumonitis (RP) after SBRT ranges from $7 \%$ to $16 \%{ }^{6,9-11}$

The estimated risk of second primary lung cancer (SPLC) after prior lung resection (PLR) ranges from 3\% to $6 \%$ per person-year and does not diminish over time. ${ }^{12}$ Thus, identification of safe treatment options for SPLC in patients with PLR is an important clinical need. The published data on curative treatment of lung tumors with SBRT after PLR are limited to small series, but SBRT has been shown to be safe for stage I lung tumors that arose after prior pneumonectomy. ${ }^{13-15}$ Thus, we present a large series of patients with PLR which include pneumonectomy, lobectomy, or wedge resection treated with SBRT for subsequent malignancies and compare their outcomes and tolerability to those of a cohort of patients without PLR who received SBRT as initial therapy for a lung tumor.

\section{MATERIALS AND METHODS}

\section{Patients}

After obtaining institutional review board approval, 132 patients with 143 peripheral lung cancers including primary early stage NSCLC and lung oligometastases treated with SBRT at our institution were retrospectively reviewed from 2009 to 2013 . A total of 130 patients with 141 tumors were included in the study after 2 patients who had prior radiofrequency ablation were excluded. Fifty patients (38\%) with 54 tumors $(38 \%)$ who had previously undergone lung resection were included in the PLR group. The non-PLR control group included 80 patients with 87 tumors.

\section{Clinical Variables}

Pretreatment patient, tumor and treatment characteristics including details of PLR, SBRT treatment, and dose-volume histogram data for the lung(s), esophagus and chest wall were collected. 


\begin{tabular}{|c|c|c|c|c|}
\hline & $\begin{array}{l}\text { All Patients }(N=130 \\
\text { Tumors }=141)\end{array}$ & $\begin{array}{l}\text { PLR }(N=50 ; \\
\text { Tumors }=54)\end{array}$ & $\begin{array}{l}\text { No } \operatorname{PLR}(\mathbf{N}=80 ; \\
\quad \text { Tumors }=87)\end{array}$ & $\boldsymbol{P}$ \\
\hline \multicolumn{5}{|l|}{ Patient characteristics } \\
\hline \multicolumn{5}{|l|}{$\operatorname{Sex}(\mathrm{n}[\%])$} \\
\hline Male & $58(44.6)$ & $21(42)$ & $37(46.2)$ & 0.72 \\
\hline Female & $72(55.4)$ & $29(58)$ & $43(53.8)$ & \\
\hline Median age (range) $(\mathrm{y})$ & $70(42-93)$ & $67(46-87)$ & $74(42-93)$ & $<0.01$ \\
\hline \multicolumn{5}{|l|}{ Race (n [\%]) } \\
\hline White & $121(93.1)$ & $47(94)$ & $74(92.5)$ & 0.10 \\
\hline Black & $7(5.4)$ & $1(2)$ & $6(7.5)$ & \\
\hline Asian & $1(0.8)$ & $2(2)$ & $0(0.0)$ & \\
\hline Hispanic & $1(0.8)$ & $1(2)$ & $0(0.0)$ & \\
\hline \multicolumn{5}{|l|}{ PS (n [\%]) } \\
\hline $0-1$ & 101 (71.6) & $47(87)$ & $54(62.1)$ & 0.01 \\
\hline $2-4$ & $40(28.4)$ & $7(13)$ & $33(37.9)$ & \\
\hline \multicolumn{5}{|l|}{ Smoking (n [\%]) } \\
\hline Current & $27(20.8)$ & $10(20)$ & $17(21.3)$ & 0.70 \\
\hline Former & 84 (64.6) & $31(62)$ & $53(66.2)$ & \\
\hline Never & 19 (14.6) & $9(18)$ & $10(12.5)$ & \\
\hline Median pack-years (range) & $41.5(0-180)$ & $38.8(0-100)$ & $45(0-180)$ & 0.08 \\
\hline History of COPD (n [\%]) & $51(39.2)$ & $15(30)$ & $36(45)$ & 0.1 \\
\hline Previous thoracic RT(n [\%]) & $29(20.6)$ & $15(27.8)$ & $14(16.1)$ & 0.13 \\
\hline Prior radiation dose (range) (Gy) & $\begin{array}{c}60(45-68.4) \\
(\mathrm{N}=23)\end{array}$ & $\begin{array}{l}60(50.4-68) \\
(\mathrm{N}=13)\end{array}$ & $\begin{array}{l}61.6(45-68.4) \\
(\mathrm{N}=10)\end{array}$ & 0.93 \\
\hline Median \% DLCO predicated (range) & $\begin{array}{l}53(5-142) \\
(\mathrm{N}=80)\end{array}$ & $\begin{array}{l}55.5(11-109) \\
(\mathrm{N}=34)\end{array}$ & $\begin{array}{l}52(5-142) \\
(\mathrm{N}=46)\end{array}$ & 0.23 \\
\hline Median DLCO (range) & $\begin{array}{c}11.3(0.9-39.2) \\
(\mathrm{N}=78)\end{array}$ & $\begin{array}{c}13(2.3-28.7) \\
(\mathrm{N}=34)\end{array}$ & $\begin{array}{l}10.3(0.9-39.2) \\
\quad(\mathrm{N}=44)\end{array}$ & 0.04 \\
\hline Median FEV1 (range) & $\begin{array}{l}1.7(0.5-5.0) \\
(\mathrm{N}=122)\end{array}$ & $\begin{array}{l}1.8(0.7-5.0) \\
(\mathrm{N}=47)\end{array}$ & $\begin{array}{c}1.7(0.5-4.9) \\
(\mathrm{N}=75)\end{array}$ & 0.50 \\
\hline Median \% FEV1 predicated (range) & $\begin{array}{l}71.5(20-127) \\
(\mathrm{N}=120)\end{array}$ & $\begin{array}{c}73.5(23-127) \\
(\mathrm{N}=46)\end{array}$ & $\begin{array}{l}69(20-125) \\
(\mathrm{N}=74)\end{array}$ & 0.79 \\
\hline \multicolumn{5}{|l|}{ Tumor characteristics } \\
\hline Recurrent tumor (n [\%]) & $29(20.6)$ & $20(37)$ & $9(10.3)$ & $<0.01$ \\
\hline \multicolumn{5}{|l|}{ Clinical T-stage (n [\%]) } \\
\hline T1a & $61(43.3)$ & $27(50)$ & $34(39.1)$ & $<0.01$ \\
\hline $\mathrm{T} 1 \mathrm{~b}$ & $32(22.7)$ & $6(11.1)$ & $26(29.9)$ & \\
\hline $\mathrm{T} 2 \mathrm{a}$ & $20(14.2)$ & $3(5.6)$ & $17(19.5)$ & \\
\hline $\mathrm{T} 2 \mathrm{~b}$ & $1(0.7)$ & $0(0.0)$ & $1(1.2)$ & \\
\hline T3 & $1(0.7)$ & $0(0.0)$ & $1(1.2)$ & \\
\hline Tx (metastases) & $26(18.4)$ & $18(33.3)$ & $8(9.2)$ & \\
\hline \multicolumn{5}{|l|}{ Overall stage (n [\%]) } \\
\hline IA & $87(61.7)$ & $31(57.4)$ & $56(64.4)$ & 0.02 \\
\hline IB & $17(12.1)$ & $3(5.6)$ & $14(16.1)$ & \\
\hline IIA & $1(0.7)$ & 0 & $1(1.2)$ & \\
\hline IIB & $1(0.7)$ & 0 & $1(1.2)$ & \\
\hline IV & $35(24.8)$ & $20(37)$ & $15(17.2)$ & \\
\hline \multicolumn{5}{|l|}{ Tumor location (n [\%]) } \\
\hline RUL & $34(24.1)$ & $10(18.5)$ & $24(27.6)$ & 0.46 \\
\hline RML & $14(9.9)$ & $4(7.4)$ & $10(11.5)$ & \\
\hline RLL & $31(22)$ & $16(29.6)$ & $15(17.2)$ & \\
\hline LUL & $27(19.2)$ & 9 (16.7) & $18(20.7)$ & \\
\hline LLL & $35(24.8)$ & $15(27.8)$ & $20(23.0)$ & \\
\hline LL & $66(46.8)$ & $31(57.4)$ & $35(40.2)$ & 0.09 \\
\hline \multicolumn{5}{|l|}{ Histology (n [\%]) } \\
\hline Adenocarcinoma & $54(38.3)$ & $17(31.5)$ & $37(42.5)$ & $<0.01$ \\
\hline Squamous cell & $28(19.9)$ & $8(14.8)$ & $20(23.0)$ & \\
\hline NSCLC NOS & $16(11.4)$ & $3(5.6)$ & $13(14.9)$ & \\
\hline Metastasis from other site & $26(18.4)$ & $18(33.3)^{*}$ & $8(9.2)$ & $<0.01$ \\
\hline None $\dagger$ & 15 (10.6) & $8(14.8)$ & $7(8.1)$ & \\
\hline \multicolumn{5}{|l|}{ Tumor grade (n [\%]) } \\
\hline No grade reported & $82(58.2)$ & $32(59.3)$ & $50(57.5)$ & 0.91 \\
\hline Grade 1 & $6(4.3)$ & $3(5.6)$ & $3(3.5)$ & \\
\hline Grade 2 & $23(16.3)$ & $8(14.8)$ & $15(17.2)$ & \\
\hline Grade 3 & $30(21.3)$ & $11(20.4)$ & $19(21.8)$ & \\
\hline Median clinical tumor size (range) & $1.9(0.7-5.5)$ & $1.6(0.8-4.2)$ & $2.4(0.7-5.5)$ & $<0.01$ \\
\hline Median pretreatment SUVmax (range) & $\begin{array}{l}5(0-21.7) \\
(\mathrm{N}=105)\end{array}$ & $\begin{array}{l}3.5(0-19) \\
(\mathrm{N}=31)\end{array}$ & $\begin{array}{l}5.9(0-21.7) \\
(\mathrm{N}=74)\end{array}$ & 0.01 \\
\hline
\end{tabular}




\begin{tabular}{|c|c|c|c|c|}
\hline & $\begin{array}{l}\text { All Patients }(N=130 ; \\
\text { Tumors }=141)\end{array}$ & $\begin{array}{l}\text { PLR }(N=50 \\
\text { Tumors }=54)\end{array}$ & $\begin{array}{l}\text { No } \operatorname{PLR}(\mathrm{N}=80 \\
\quad \text { Tumors }=87)\end{array}$ & $\boldsymbol{P}$ \\
\hline \multicolumn{5}{|l|}{ Treatment characteristics } \\
\hline \multicolumn{5}{|l|}{ SBRT technique (n [\%]) } \\
\hline Conformal & $113(80.1)$ & $44(81.5)$ & $69(79.3)$ & 0.83 \\
\hline VMAT & $28(19.9)$ & $10(18.5)$ & $18(20.7)$ & \\
\hline $\begin{array}{l}\text { Median prescribed radiation dose (range) } \\
\text { (Gy) }\end{array}$ & $54(40.5-60)$ & $54(40.5-60)$ & $54(48-60)$ & $<0.01$ \\
\hline $\begin{array}{l}\text { Median prescribed dose per fraction } \\
\text { (range) (Gy) }\end{array}$ & $18(10-19.7)$ & $18(10-18)$ & $18(10-19.7)$ & $<0.01$ \\
\hline Median delivered BED (range) $\left(\mathrm{Gy}_{10}\right)$ & $151.2(95.2-175.5)$ & $\begin{array}{l}151.2(95.2-151.2) \\
\quad(\text { mean }=144.8)\end{array}$ & $\begin{array}{l}151.2(100-175.5) \\
\quad(\operatorname{mean}=138.1)\end{array}$ & 0.01 \\
\hline \multicolumn{5}{|l|}{ Chemotherapy (n [\%]) } \\
\hline Induction & $11(7.8)$ & $2(3.7)$ & $9(10.3)$ & 0.2 \\
\hline Adjuvant & $4(2.8)$ & $2(3.7)$ & $2(2.3)$ & 0.64 \\
\hline \multicolumn{5}{|l|}{ DVH } \\
\hline ITV (mL) & $8.7(0.5-82.9)$ & $4.6(0.7-40.9)$ & $12.1(0.5-82.9)$ & $<0.01$ \\
\hline PTV (mL) & $24.6(4.9-110.6)$ & $16.6(5.8-110.6)$ & $31.7(4.9-109.4)$ & $<0.01$ \\
\hline Lung V5 (\%) & $17(2.7-39.1)$ & $15.3(8.3-37.4)$ & $18(2.7-39.1)$ & 0.03 \\
\hline Lung V20 (\%) & $4(1.2-10.8)$ & $3.9(1.2-10.3)$ & $4.1(1.3-10.8)$ & 0.08 \\
\hline Lung MLD (Gy) & $3.6(0.9-7.8)$ & $3.1(1.6-7.8)$ & $3.7(0.9-7.6)$ & 0.01 \\
\hline Contralateral lung V5 (\%; VMAT only) & $2.1(0.0-29.0)$ & & & \\
\hline Lung D1000cc (Gy) & $1.3(0.2-9.0)$ & $1.0(0.2-3.7)$ & $2.0(0.2-9.0)$ & $<0.01$ \\
\hline Lung D1500cc (Gy) & $0.5(0.0-3.7)$ & $0.4(0.0-2.3)$ & $0.6(0.0-3.7)$ & $<0.01$ \\
\hline Lung V10.5 (3-fraction) (mL) & $\begin{array}{l}257.9(43.5-635.7) \\
\quad(\mathrm{N}=93)\end{array}$ & $\begin{array}{l}242.7(101.8-451.9) \\
\quad(\mathrm{N}=44)\end{array}$ & $\begin{array}{l}291.8(43.5-635.7) \\
\quad(\mathrm{N}=49)\end{array}$ & 0.04 \\
\hline Lung V11.4 (3-fraction) (mL) & $\begin{array}{l}230.9(42.2-581.4) \\
\quad(\mathrm{N}=93)\end{array}$ & $\begin{array}{l}217.0(91.8-417.0) \\
\quad(\mathrm{N}=44)\end{array}$ & $\begin{array}{l}263.0(42.2-581.1) \\
\quad(\mathrm{N}=49)\end{array}$ & 0.04 \\
\hline Lung V12.5 (5-fraction) $(\mathrm{mL})$ & $\begin{array}{l}312.9(40.7-721.3) \\
\quad(\mathrm{N}=42)\end{array}$ & $\begin{array}{c}261.3(124.8-360.9) \\
(\mathrm{N}=7)\end{array}$ & $\begin{array}{l}337.1(40.7-721.3) \\
\quad(\mathrm{N}=35)\end{array}$ & 0.08 \\
\hline Lung V13.5 (5-fraction) $(\mathrm{mL})$ & $\begin{array}{l}277.1(39.5-649.7) \\
\quad(\mathrm{N}=42)\end{array}$ & $\begin{array}{l}237.2(110.3-335.5) \\
\quad(\mathrm{N}=7)\end{array}$ & $\begin{array}{l}299.3(39.5-649.7) \\
\quad(\mathrm{N}=35)\end{array}$ & 0.07 \\
\hline Chest wall V30 (mL) & $15.5(0-88.5)$ & $13.2(0-56.4)$ & $18.1(0-88.5)$ & $<0.01$ \\
\hline Esophagus max dose $(\mathrm{Gy}, \mathrm{N}=135)$ & $10.4(0.4-33.8)$ & $\begin{array}{l}10.3(0.4-26.3) \\
\quad(\mathrm{N}=53)\end{array}$ & $\begin{array}{l}10.4(0.4-33.8) \\
\quad(\mathrm{N}=83)\end{array}$ & 0.49 \\
\hline
\end{tabular}

Values in bold represent statistically significant $(P<0.05)$.

*Sarcoma: 55.6\%; colorectal cancer: $22.2 \%$; melanoma: 5.6\%; esophageal cancer: $5.6 \%$; others: $11.1 \%$.

$\dagger$ No pathology (clinical diagnosis).

BED indicates biologically effective dose; COPD, chronic obstructive pulmonary disease; DLCO, diffusing capacity of the lung for carbon monoxide; DVH, dosevolume histogram; FEV1, forced expiratory volume in 1 second; ITV, internal target volume; LL, left lung; LLL, left lower lobe; LUL, left upper lobe; MLD, mean lung dose; NOS, not otherwise specified; NSCLC, non-small cell lung cancer; PLR, prior lung resection; PTV, planning target volume; RLL, right lower lobe; RML, right middle lobe; RUL, right upper lobe; RT, radiation therapy; Tx, unable to assess primary tumor; V5 (\%), \% volume which receives at least 5 Gy radiation dose; VMAT, volumetric modulated arc therapy.

\section{SBRT Treatment}

During the study period, SBRT was utilized only for peripheral tumors as defined in RTOG $0236 .{ }^{4}$ Patients were treated with SBRT because they were medically inoperable or unwilling to have surgery. Patients were immobilized in a custom stereotactic frame, and abdominal compression was used for patients with tumor movement $>1 \mathrm{~cm}$. For treatment planning, an internal target volume was generated from reconstructed 4-dimensional computed tomography (CT) images, and expanded by $5 \mathrm{~mm}$ to obtain a planning target volume (PTV) margin without clinical target volume margin. SBRT was delivered in 3 to 5 fractions. Daily setup included Exac Trac and cone-beam CT before treatment on a linear accelerator.

\section{Planning Parameters and Dose-Volume Histogram Constraints}

Plans were prescribed to achieve 95\% coverage of the PTV with $100 \%$ of the prescription dose, with typical normalization to the $60 \%$ to $80 \%$ isodose line. Lung constraints included V20 $<10 \%$, mean lung dose $<7 \mathrm{~Gy}$, and critical volume constraints (D1000cc $<11.4$ and $<13.5 \mathrm{~Gy}$, and D1500cc $<10.5$ and 12.5 Gy for 3- and 5fraction cases, respectively) for all cases, and contralateral V $5<26 \%$ for patients receiving Volumetric Modulated Arc therapy. The 3and 5-fraction constraints for the other organs at risk were comparable with National Comprehensive Cancer Network guidelines.

\section{Follow-up}

After treatment, patients were typically followed with clinic visits and restaging chest CT at 3 to 6 month intervals for the first 2 years, then 6 to 12 month intervals thereafter.

\section{Outcomes}

Primary tumor control (TC) and local (lobar) control (LC) were defined as per RTOG $0236 .{ }^{4} \mathrm{TC}$, LC, regional control, local-regional control, freedom from any recurrence, freedom from distant metastases, recurrence-free survival, OS were analyzed, and time to each event was measured from the date of the last SBRT treatment. Toxicity events including RP, esophagitis, and chest wall pain were scored using the Common Terminology Criteria for Adverse Events version 4.0. 


\begin{tabular}{lc}
\hline TABLE 2. Details of PLR & \\
\hline & $\begin{array}{c}\text { PLR Before SBRT } \\
\text { (N=50; Tumors =54) }\end{array}$ \\
\hline PLR site relative to SBRT (n [\%]) & $11(22)$ \\
Same lobe & $16(32)$ \\
Ipsilateral different lobe & $23(46)$ \\
Contralateral lobe & $1(1-7)$ \\
Median number of PLRs per patient (range) & $1(0-7)$ \\
Wedge resection (range) & $0(0-2)$ \\
Lobectomy (range) & $0(0-1)$ \\
Pneumonectomy (range) & $21(42)$ \\
Most extensive PLR type (n [\%]) & $23(46)$ \\
Wedge resection & $6(12)$ \\
Lobectomy & $33.4(0.95-206.3)$ \\
Pneumonectomy & \\
Time from PLR to SBRT (range) (mo) & \\
\hline \multicolumn{2}{c}{ PLR indicates prior lung resection; SBRT, stereotactic body radiation } \\
therapy.
\end{tabular}

\section{Statistical Analyses}

For TC, LC, and toxicity, all 141 tumors were included, but all other endpoints were calculated per patient. The Fisher exact and the Wilcoxon rank sum tests were used to detect differences by PLR status in the distribution of categorical variables and continuous variables. Survival and patterns of failure between patients with and without PLR were compared using the Kaplan-Meier method and the log-rank test, while toxicities were analyzed with the cumulative incidence method and the Gray test.

Cox proportional hazard regression was performed to identify predictors for $\mathrm{TC}$ for all patients. Fine and Gray regression for competing risk was used to evaluate predictors for RP for all patients. Clinical variables with a $P$-value $<0.10$ in univariable analysis were included in the multivariable analysis as potential confounders. All statistical analyses were performed using SAS version 9.4 (Carey, NC).

\section{RESULTS}

\section{Patient and Tumor Characteristics}

As shown in Table 1, patients with PLR were significantly younger, had better performance status and diffusing capacity of the lung for carbon monoxide, and had smaller tumors. Recurrent tumors and lung metastasis constituted a significantly higher proportion of the PLR group. There was a nonsignificant trend for a higher incidence of prior thoracic radiotherapy in patients with PLR.

\section{PLR Characteristics}

As shown in Table 2, lobectomy and wedge resection were the most common PLR (88\%). The number of PLR per patient ranged from 1 to 7 . About $46 \%$ PLRs were contralateral to the SBRT site.

\section{SBRT Treatment Characteristics}

Dosimetric data are shown in Table 1. Patients with PLR received a higher biologically effective dose $(\mathrm{BED} ; P=0.01)$, lower dose to the lungs including V5 $(P=0.03)$ and mean lung dose (MLD) $(P=0.01)$, and lower dose to the chest wall V30 $(P<0.01)$.

\section{Outcomes}

With a median follow-up of 21 months in survivors, outcomes are shown in Table 3. Patients with PLR had higher TC (1-y $100 \%$ vs. $93 \%, P<0.01$, Fig. 1 ), but there was no difference in OS ( 1 and $2 y$ ) nor other patterns of failure. The higher TC in PLR patients remained significant in the subset of patients with primary lung tumors, but not in patients with oligometastases (Table 3).

Patients with PLR had increased risk of grade $2 \geq 2$ RP (1-y cumulative incidence $12 \%$ vs. $1 \%, P<0.01$, Fig. 2 ) and grade $\geq 2$ any toxicity (1-y cumulative incidence $16 \%$ vs. $4 \%$, $P=0.01)$. Six patients with PLR developed RP (4 grade 2 and 2 grade $3 ; 1$ pneumonectomy case, 2 lobectomy cases, and 3 wedge cases) and all were former smokers. Among these 6 , 3 received chemotherapy ( 1 induction and 2 adjuvant therapy)

\begin{tabular}{|c|c|c|c|c|}
\hline 1- and 2-Year Estimates & All $(N=130 ; 141$ Tumors $)$ & PLR (N=50; 54 Tumors) & No PLR $(\mathrm{N}=80 ; 87$ Tumors $)$ & $\boldsymbol{P}$ \\
\hline \multicolumn{5}{|c|}{ Survival and tumor control (crude events) (n [\%]) } \\
\hline TC & $5(95) / 9(90)$ & $0(100) / 0(100)$ & $5(93) / 9(849)$ & $<0.01$ \\
\hline TC in Primary Lung Tumors & $\begin{array}{c}5(94) / 8(89) \\
(115 \text { tumors) }\end{array}$ & $\begin{array}{l}0(100) / 0(100) \\
(36 \text { tumors })\end{array}$ & $\begin{array}{l}5(92) / 8(85) \\
\text { (79 tumors) }\end{array}$ & 0.03 \\
\hline $\mathrm{TC}$ in Oligometastases & $\begin{array}{l}0(100) / 1(91) \\
(26 \text { tumors) }\end{array}$ & $\begin{array}{l}0(100) / 0(100) \\
(18 \text { tumors })\end{array}$ & $\begin{array}{l}0(100) / 1(75) \\
(8 \text { tumors })\end{array}$ & 0.19 \\
\hline $\mathrm{RC}$ & $12(89) / 16(84)$ & $4(90) / 4(90)$ & $8(88) / 12(80)$ & 0.18 \\
\hline LRC & $22(80) / 31(67)$ & $9(79) / 10(73)$ & $13(80) / 21(64)$ & 0.6 \\
\hline FFDM & $43(63) / 51(52)$ & $20(54) / 22(45)$ & $23(67) / 29(57)$ & 0.33 \\
\hline FFR & $49(57) / 57(48)$ & $21(53) / 23(43)$ & $28(60) / 34(50)$ & 0.64 \\
\hline OS & $16(87) / 47(57)$ & $4(91) / 16(56)$ & $12(85) / 31(57)$ & 0.24 \\
\hline RFS & $55(56) / 73(38)$ & $22(52) / 27(34)$ & $33(58) / 46(40)$ & 0.86 \\
\hline \multicolumn{5}{|c|}{ Toxicity (cumulative incidence) (\%) } \\
\hline Any toxicity $\geq$ grade 2 & $8 / 10$ & $16 / 18$ & $4 / 5$ & 0.01 \\
\hline $\mathrm{RP} \geq$ grade 2 & $5 / 5$ & $12 / 12$ & $1 / 1$ & $<0.01$ \\
\hline Esophagitis $\geq$ grade 2 & $1 / 1$ & $0 / 0$ & $1 / 1$ & 0.43 \\
\hline $\mathrm{CW}$ pain $\geq$ grade 2 & $2 / 4$ & $4 / 7$ & $1 / 2$ & 0.26 \\
\hline
\end{tabular}

Median follow-up $=17.4$ mo among the 130 patients

Values in bold represent statistically significant $(P<0.05)$.

CW indicates chest wall; FFDM, freedom from distant metastases; FFR, freedom from any recurrence, LRC, local-regional control; OS, overall survival; PLR, prior lung resection; RFS, recurrence-free survival; RP, radiation pneumonitis; TC, tumor control. 


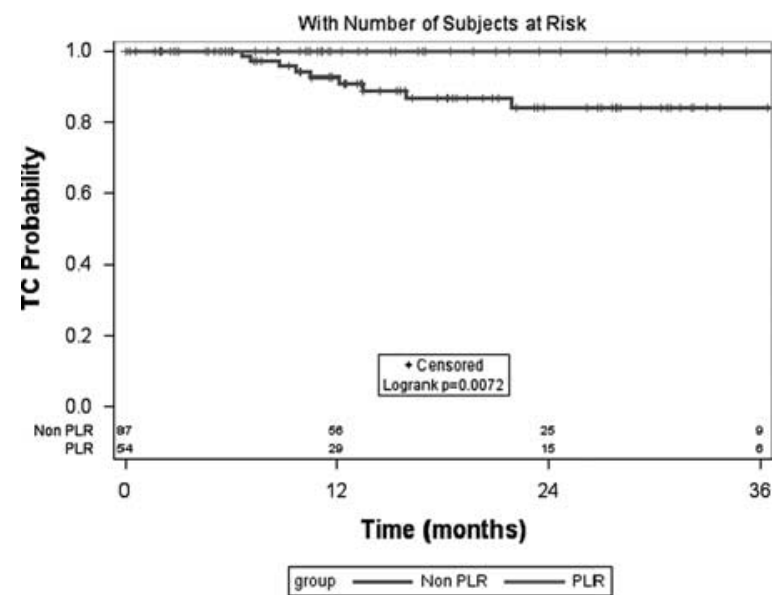

FIGURE 1. Difference of the Kaplan-Meier plots of TC in patients with and without PLR. Patients with PLR had significantly better TC than those without PLR. PLR indicates prior lung resection; TC, tumor control.

and 2 had prior radiation. The 6 PLR patients who developed RP had a median V5, V20, MLD, D1000cc, D1500cc, PTV, and internal target volume of $19.6 \%, 3.5 \%, 3.5 \mathrm{~Gy}, 0.67 \mathrm{~Gy}$, $0.25 \mathrm{~Gy}, 15.9$, and $4.2 \mathrm{~mL}$, respectively, when compared with $14.7 \%, 4.0 \%, 3.1 \mathrm{~Gy}, 0.98 \mathrm{~Gy}, 0.37 \mathrm{~Gy}, 16.6$, and $4.5 \mathrm{~mL}$, respectively for patients $(\mathrm{N}=48)$ without RPs in PLR group.

\section{Univariable/Multivariable Analysis}

On univariable Cox regression for all patients, chemotherapy and BED were associated with improved TC, but only BED was associated with TC (hazard ratios [HR], 0.97; 95\% confidence interval $[\mathrm{CI}], 0.94-0.999 ; P=0.04$ ) on multivariable analysis.

Univariable Fine and Gray regression demonstrated PLR, chemotherapy and tumor grade were associated with grade $\geq 2$ RP. Prior thoracic radiation $(P=0.58)$, recurrent tumors $(P=0.15)$ and lung metastasis $(P=0.12)$ were not found associated with increased RP in our univariable Fine and Gray regression model (Table 4). As shown in Table 4, there was a significant increase in RP for pneumonectomy versus non-PLR group (HR, 15.30; 95\% CI, 1.08-217.48; $P=0.04$ ) compared with the trend of increased RP in lobectomy versus non-PLR group (HR, 7.06; 95\% CI, 0.64-77.51; $P=0.11)$ and wedge resection versus non-PLR group (HR, 8.80; 95\% CI, 0.9284.48; $P=0.06$ ). However, on multivariable analysis, only chemotherapy use (HR, 14.92; 95\% CI, 5.68-39.21; $P<0.0001$ ) remained associated with grade $\geq 2$ RP (Table 4 ). After adjusting for chemotherapy use and other confounders identified on univariable analysis, PLR was not associated with increased grade $\geq 2$ RP.

\section{DISCUSSION}

In this study, patients treated with SBRT for peripheral lung tumors had overall high TC (1-y 100\%) and low incidences of severe toxicity in all patients with or without PLR, which is comparable with previously published data. ${ }^{3-11}$ Tumor-related outcomes were not significantly different between patients with or without PLR except a finding of increased TC in patients with PLR. PLR's association with TC could not be evaluated on multivariate analysis because of zero TC failure events in the PLR group. In addition, there was a

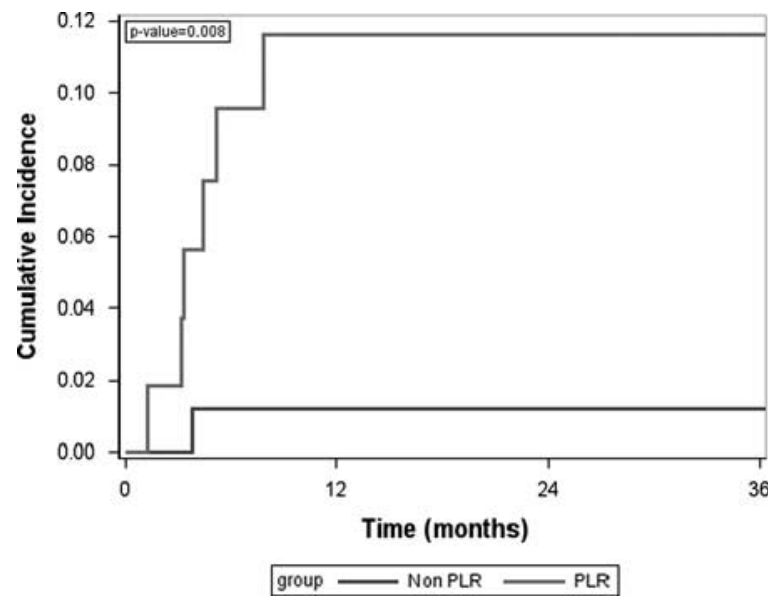

FIGURE 2. Comparison of cumulative incidence plots of grade $\geq 2$ radiation pneumonitis between patients with and without PLR. Patients with PLR had significantly higher rate of grade $\geq 2$ radiation pneumonitis than those without PLR. PLR indicates prior lung resection.

significantly higher incidence of grade $\geq 2 \mathrm{RP}$ in patients with PLR with a 1 -year estimate of $12 \%$ versus $1 \%$ on univariate analysis, but this association with PLR was not significant on multivariable analysis after adjusting for use of chemotherapy and other confounders.

Contrasting our findings with the existing literature, Haasbeek et $\mathrm{al}^{13}$ described a series of 15 patients treated with SBRT for a SPLC after prior pneumonectomy and reported a LC of $100 \%$ and 2 cases $(13 \%)$ of grade $\geq 3$ RP. Thompson et $\mathrm{al}^{15}$ demonstrated SBRT outcomes on patients with previous pneumonectomy $(\mathrm{N}=14)$ with 2-year OS of $61 \%$, LC of $100 \%$, and 2 cases of grade $\geq 3$ RP $(14 \%)$. Xiong et al ${ }^{16}$ noted 1 -year LC of $91 \%$, and grade $\geq 2$ RP (including either cough and/or dyspnea) of $35 \%(\mathrm{~N}=23)$ treated with SBRT for isolated lung metastasis after lobectomy. Griffioen et al ${ }^{17}$ showed 3-year OS of $60 \%, 3$-year LC of $89 \%$ and uncommon RP (acute grade 2: $<1 \%$; late grade $2: 7 \%$; late grade $\geq 3: 3.7 \%$ ) for 107 patients who had undergone surgery (73\% (bi)lobectomy) and treated with SBRT for SPLC. Hayes et al ${ }^{18}$ reported nonstatistically significant difference in post-SBRT RP risk between patients with $(\mathrm{N}=17)$ and without $(\mathrm{N}=71)$ prior (bi)lobectomy or pneumonectomy (2-y $11 \%$ vs. $3 \% ; P=0.51)$.

In comparison to these prior studies, we explored risk of toxicity in patients with both nonanatomic (wedge resection) and anatomic (lobectomy or pneumonectomy) and analyzed the data using a competing risk cumulative incidence method. In our study, PLR was also not associated with increased risk of grade $\geq 2$ RP on multivariate analysis. However, definitive conclusions cannot be made due to the small sample sizes in each subgroup, and the small number of RP events overall. Our univariable/multivariable results suggest PLR and RP association may be confounded by chemotherapy, and there might be other unevaluated confounders beyond those analyzed in this study. Further exploration regarding PLR and its potential association with symptomatic RP in patients receiving SBRT (eg, anatomic location, extent of resection, and timing of resection) in larger cohorts is required.

Chemotherapy use before or after SBRT was associated with increased RP in all patients. Among the patients with PLR in this study, $7 \%$ had sequential chemotherapy. In comparison 


\begin{tabular}{|c|c|c|c|c|}
\hline \multirow[b]{2}{*}{ Covariate } & \multicolumn{2}{|c|}{$\begin{array}{c}\text { Univariable For All } \\
\text { Patients (141 Tumors) }\end{array}$} & \multicolumn{2}{|c|}{$\begin{array}{l}\text { Multivariable For All } \\
\text { Patients (141 Tumors) }\end{array}$} \\
\hline & HR $(95 \%$ CI $)$ & $\boldsymbol{P}$ & HR $(95 \%$ CI $)$ & $\boldsymbol{P}$ \\
\hline Age $<$ median age vs. $\geq$ median & $\begin{array}{l}3.26(0.65-16.37) \\
(\text { median }=70)\end{array}$ & 0.15 & & \\
\hline Female vs. male & $4.79(0.60-38.17)$ & 0.14 & & \\
\hline Pack-years $<$ median vs. $\geq$ median & $\begin{array}{l}1.22(0.28-5.37) \\
(\text { median }=41.5)\end{array}$ & 0.79 & & \\
\hline FEV1 $<$ median vs. $\geq$ median $(\mathrm{L})$ & $\begin{array}{l}0.36(0.07-1.90) \\
(\text { median }=1.7)\end{array}$ & 0.23 & & \\
\hline History of COPD vs. none & $0.70(0.14-3.61)$ & 0.67 & & \\
\hline History of prior thoracic RT vs. none & $1.59(0.31-8.13)$ & 0.58 & & \\
\hline Recurrent tumor vs. none & $2.97(0.69-12.88)$ & 0.15 & & \\
\hline \multicolumn{5}{|l|}{ T-stage } \\
\hline T1b vs. T1a & $0.60(0.07-5.47)$ & 0.65 & & \\
\hline Tumor size $<$ median vs. $\geq$ median $(\mathrm{cm})$ & $\begin{array}{l}1.81(0.40-8.10) \\
(\text { median }=1.9)\end{array}$ & 0.44 & & \\
\hline Lower lobe vs. upper/middle lobe & $1.55(0.35-6.88)$ & 0.56 & & \\
\hline \multicolumn{5}{|l|}{ Histology } \\
\hline Lung metastasis vs. primary tumor & $3.16(0.74-13.59)$ & 0.12 & & \\
\hline Clinical diagnosis vs. biopsy proven & $1.44(0.17-12.37)$ & 0.74 & & \\
\hline Adenocarcinoma vs. others & $1.34(0.30-5.92)$ & 0.70 & & \\
\hline Tumor grade 3 vs. grades 1-2/unknown & $4.78(1.09-20.95)$ & 0.04 & $1.16(0.18-7.40)$ & 0.87 \\
\hline PLR & $10.20(1.23-84.85)$ & 0.03 & $8.26(0.73-93.87)$ & 0.09 \\
\hline Pneumonectomy vs. none & $15.30(1.08-217.48)$ & 0.04 & & \\
\hline Lobectomy vs. none & $7.06(0.64-77.51)$ & 0.11 & & \\
\hline Wedge vs. none & $8.80(0.92-84.48)$ & 0.06 & & \\
\hline BED $<$ median vs. $\geq$ median (Gy) & $0.31(0.04-2.56)($ median $=151.2)$ & 0.28 & & \\
\hline VMAT vs. 3D conformal & $1.64(0.32-8.31)$ & 0.55 & & \\
\hline ITV volume $<$ median vs. $\geq$ median $(\mathrm{mL})$ & $\begin{array}{l}6.73(0.81-55.69) \\
(\text { median }=8.7)\end{array}$ & 0.08 & $3.55(0.73-17.27)$ & 0.12 \\
\hline Lung V20 $<$ median vs. $\geq$ median $(\%)$ & $\begin{array}{l}1.42(0.32-6.26) \\
(\text { median }=4)\end{array}$ & 0.64 & & \\
\hline Lung MLD $<$ median vs. $\geq$ median (Gy) & $\begin{array}{l}0.67(0.15-2.97) \\
(\text { median }=3.6)\end{array}$ & 0.60 & & \\
\hline Chemotherapy vs. no chemotherapy & $11.26(2.59-49.04)$ & $<0.01$ & $14.92(5.68-39.21)$ & $<0.0001$ \\
\hline Adjuvant chemotherapy vs. no chemotherapy & $19.90(4.37-102.56)$ & $<0.01$ & & \\
\hline Induction chemotherapy vs. no chemotherapy & $7.41(1.34-40.97)$ & 0.02 & & \\
\hline
\end{tabular}

Values in bold represent statistically significant $(P<0.05)$

BED indicates biologically effective dose; CI, confidence interval; COPD, chronic obstructive pulmonary disease; 3D, 3-dimensional; HR, hazard ratios; FEV1, forced expiratory volume in 1 second; ITV, internal target volume; MLD, mean lung dose; PLR, prior lung resection; RT, radiation therapy; V20 (\%), \% volume which receives at least 20 Gy radiation dose; VMAT, volumetric modulated arc therapy.

with other postsurgical SBRT series, Griffioen and colleagues included very few patients with chemotherapy $(1.9 \%)$, and demonstrated a very low incidence of symptomatic RP, while Xiong et $\mathrm{al}^{16}$ included many patients treated with prior chemotherapy (78\%) and showed the highest incidence of $35 \%$ symptomatic pneumonitis. ${ }^{18}$ In this series, 2 of the 6 PLR patients who developed symptomatic RP received adjuvant chemotherapy. Nevertheless, these imbalances in chemotherapy utilization may reflect differences in the composition of each series, which may also introduce unmeasured confounders.

Prior studies demonstrate that the risk of RP after SBRT is associated with MLD, V20 $0^{11}$ and V5. ${ }^{19}$ PTV size and ipsilateral lung V5 were also found to be potential predictors for post-SBRT RP grade $\geq 2$ for isolated lung metastasis with prior lobectomy. ${ }^{16}$ However, none of the dosimetric parameters were associated with RP risk in our series. Our PLR group in general had significantly smaller tumors and lower V5 and MLD compared with patients without PLR, and the 6 patients that did develop symptomatic RP had acceptably low lung metrics. Thus, while clinicians should be mindful of a potential increased risk of RP in patients with PLR and optimize lung metrics in this subgroup of patients by more conservative constraints, the overall risk of symptomatic RP remains low and these patients should continue to be candidates for curative SBRT for second primary lung tumors or lung metastases.

The findings of this study must be interpreted in the context of the study design, and limitations include possible underestimating of RP events in a retrospective analysis, small number of toxicity events that may lead to overfitting of the regression models, and lack of post-SBRT PFT data to objectively measure pulmonary decline.

\section{CONCLUSIONS}

In this series describing clinical outcomes and toxicity for patients treated with SBRT with PLR, we demonstrate high local control and relatively low incidence of symptomatic toxicity. There was no significant association between PLR and symptomatic RP on multivariable analysis after adjusting for chemotherapy as a confounder, but this potential association warrants further study. Thus, SBRT is an excellent option to treat second lung tumors or pulmonary metastases in patients with PLR who are not candidates for further surgery. 


\section{ACKNOWLEDGMENTS}

The authors thank Mrs Elizabeth Bales and Ms Ying So from SAS Institute, North Carolina for their help on SAS programming.

\section{REFERENCES}

1. Siegel R, Naishadham D, Jemal A. Cancer statistics, 2013. $C A$ Cancer J Clin. 2013;63:11-30.

2. Goldstraw P, Crowley J, Chansky K, et al. The IASLC Lung Cancer Staging Project: proposals for the revision of the TNM stage groupings in the forthcoming (seventh) edition of the TNM Classification of malignant tumours. J Thorac Oncol Off Publ Int Assoc Study Lung Cancer. 2007;2:706-714.

3. Timmerman R, McGarry R, Yiannoutsos C, et al. Excessive toxicity when treating central tumors in a phase II study of stereotactic body radiation therapy for medically inoperable early-stage lung cancer. $J$ Clin Oncol Off J Am Soc Clin Oncol. 2006;24:4833-4839.

4. Timmerman R, Paulus R, Galvin J, et al. Stereotactic body radiation therapy for inoperable early stage lung cancer. JAMA $J$ Am Med Assoc. 2010;303:1070-1076.

5. Baumann P, Nyman J, Hoyer M, et al. Outcome in a prospective phase II trial of medically inoperable stage I non-small-cell lung cancer patients treated with stereotactic body radiotherapy. J Clin Oncol Off J Am Soc Clin Oncol. 2009;27:3290-3296.

6. Onishi $\mathrm{H}$, Araki T, Shirato $\mathrm{H}$, et al. Stereotactic hypofractionated high-dose irradiation for stage I nonsmall cell lung carcinoma: clinical outcomes in 245 subjects in a Japanese multiinstitutional study. Cancer. 2004;101:1623-1631.

7. Grills IS, Mangona VS, Welsh R, et al. Outcomes after stereotactic lung radiotherapy or wedge resection for stage I non-small-cell lung cancer. J Clin Oncol Off J Am Soc Clin Oncol. 2010;28: 928-935.

8. Senthi S, Lagerwaard FJ, Haasbeek CJA, et al. Patterns of disease recurrence after stereotactic ablative radiotherapy for early stage non-small-cell lung cancer: a retrospective analysis. Lancet Oncol. 2012;13:802-809.

9. Borst GR, Ishikawa M, Nijkamp J, et al. Radiation pneumonitis in patients treated for malignant pulmonary lesions with hypofractionated radiation therapy. Radiother Oncol J Eur Soc Ther Radiol Oncol. 2009;91:307-313.

10. Guckenberger M, Baier K, Polat B, et al. Dose-response relationship for radiation-induced pneumonitis after pulmonary stereotactic body radiotherapy. Radiother Oncol J Eur Soc Ther Radiol Oncol. 2010;97:65-70.

11. Barriger RB, Forquer JA, Brabham JG, et al. A dose-volume analysis of radiation pneumonitis in non-small cell lung cancer patients treated with stereotactic body radiation therapy. Int $J$ Radiat Oncol Biol Phys. 2012;82:457-462.

12. Lou F, Huang J, Sima CS, et al. Patterns of recurrence and second primary lung cancer in early-stage lung cancer survivors followed with routine computed tomography surveillance. $J$ Thorac Cardiovasc Surg. 2013;145:75-81; discussion 81-82.

13. Haasbeek CJA, Lagerwaard FJ, De Jaeger K, et al. Outcomes of stereotactic radiotherapy for a new clinical stage I lung cancer arising postpneumonectomy. Cancer. 2009;115:587-594.

14. Senthi S, Haasbeek CJA, Lagerwaard FJ, et al. Radiotherapy for a second primary lung cancer arising post-pneumonectomy: planning considerations and clinical outcomes. $J$ Thorac Dis. 2013;5: 116-122.

15. Thompson R, Giuliani M, Yap ML, et al. Stereotactic body radiotherapy in patients with previous pneumonectomy: safety and efficacy. J Thorac Oncol Off Publ Int Assoc Study Lung Cancer. 2014;9:843-847.

16. Xiong $\mathrm{W}, \mathrm{Xu} \mathrm{Q}, \mathrm{Xu} \mathrm{Y}$, et al. Stereotactic body radiation therapy for post-pulmonary lobectomy isolated lung metastasis of thoracic tumor: survival and side effects. BMC Cancer. 2014;14:719.

17. Griffioen GHMJ, Lagerwaard FJ, Haasbeek CJA, et al. A brief report on outcomes of stereotactic ablative radiotherapy for a second primary lung cancer: evidence in support of routine CT surveillance. J Thorac Oncol Off Publ Int Assoc Study Lung Cancer. 2014;9:1222-1225.

18. Hayes JT, David EA, Qi L, et al. Risk of pneumonitis after stereotactic body radiation therapy in patients with previous anatomic lung resection. Clin Lung Cancer. 2015;16:379-384.

19. Baker R, Han G, Sarangkasiri S, et al. Clinical and dosimetric predictors of radiation pneumonitis in a large series of patients treated with stereotactic body radiation therapy to the lung. Int $J$ Radiat Oncol Biol Phys. 2013;85:190-195. 